\title{
Distribution of fluoride in surface and ground water: a case study of Langtang North, Plateau State, Nigeria
}

\author{
M.P. GOYIT ${ }^{1}$, O.A. SOLOMON ${ }^{1}$ and R.J. KUTSHIK ${ }^{2 *}$ \\ ${ }^{1}$ Department of Geology, Faculty of Natural Sciences, University of Jos, P.M.B 2084, Jos, \\ Plateau State, Nigeria. \\ ${ }^{2}$ Department of Biochemistry, Faculty of Medical Sciences, University of Jos, P.M.B 2084, Jos, \\ Plateau State, Nigeria. \\ *Corresponding author, E-mail: kutshik@yahoo.com,Tel: +2348098664834
}

\begin{abstract}
The major ways in which humans get exposed to inorganic fluorides are through food and water. Therefore, this study focused on fluoride concentration in surface and ground water in Langtang North of Plateau State where dental fluorosis is more predominant. Twenty-six (26) samples from ground water and four (4) from surface water were collected from six localities of Langtang-North. These samples were analyzed using ion selective method to investigate the spatial distribution of fluoride concentration. Rock and soil samples were also collected for analysis. Hydrochemical results revealed the following concentrations; 1600 $\mathrm{ppm}-2990 \mathrm{ppm}$ for fluoride in rocks, and $100 \mathrm{ppm}-600 \mathrm{ppm}$ for soil. Fluoride in water ranges from $1.1-6.0$ $\mathrm{mg} / \mathrm{l}$, whereas, $\mathrm{Na}^{+}, \mathrm{Mg}^{2+}, \mathrm{Ca}^{2+}, \mathrm{HCO}_{3}{ }^{-}, \mathrm{SO}_{4}{ }^{2-}, \mathrm{Cl}^{-}, \mathrm{Al}^{3+}$ and $\mathrm{Fe}^{2+}$ have average concentrations of $48.566 \mathrm{mg} / \mathrm{l}$, $21.220 \mathrm{mg} / \mathrm{l}, 21.142 \mathrm{mg} / \mathrm{l}, 214.27 \mathrm{mg} / \mathrm{l}, 16.492 \mathrm{mg} / \mathrm{l}, 28.641 \mathrm{mg} / \mathrm{l}, 0.177 \mathrm{mg} / \mathrm{l}$, and $0.261 \mathrm{mg} / \mathrm{l}$ respectively. Classification of the water using a Piper's trillinear method shows a Sodium bicarconate water type. Fluoride concentration in the rocks and soils could be responsible for the high concentration of fluoride present in the groundwater. Eighty three point three-three $(83.33 \%)$ percent of the samples analyzed have fluoride concentration above the $1.5 \mathrm{mg} / \mathrm{l}$ recommended by WHO, while only the remaining 16.67 percent are within the WHO recommended level. In conclusion, the amount of fluoride in rocks as compared with the soils and water sources were significant $(\mathrm{p}<0.05)$ and this could be because nature weathering and leaching that takes place. Therefore, majority of the water sources both ground and surface will need defluoridation.
\end{abstract}

(C) 2018 International Formulae Group. All rights reserved.

Keywords: Fluoride, ground water, surface water, rocks, soil.

\section{INTRODUCTION}

A major source of fluoride intake for living things is from drinking water (UNICEF, 1999; Waziri, et al., 2012). This is because the fluoride compounds in the earth's upper crust are soluble in water and available in both surface waters and groundwater (Frencken, 1992; Brunt et al., 2004). However, known factors responsible for the natural concentration of fluoride in groundwater are the physical, geological and chemical distinctiveness of the aquifer, the porosity and acidity of the soil and rocks, the temperature, the action of other chemical elements and the depth of wells (UNICEF, 1999; Paul et al., 2011; Zoulgami et al., 2015).

Fluoride is an important compound that could be beneficial or detrimental to human 
and animals, depending on the levels of its consumption in water and foods. It contributes to the remineralisation process in enamel of the tooth surface, although not completely dependent on fluoride and that fluoride's anticaries is critically dependent on calcium and magnesium content of the teeth enamel. Under nutrition in young individuals, which result to low calcium and magnesium in teeth enamel does affect fluoride ingestion and contact with teeth, makes such an individual vulnerable to dental caries (Sadashivamurthy and Deshmukh, 2012). High levels of fluoride $(>1.5 \mathrm{mg} / \mathrm{L})$ may result in mottled teeth (dental fluorosis) in children less than 7 years of age, $>4 \mathrm{mg} / \mathrm{l}$ dental and skeletal fluorosis, low IQ, reduced immunity and hip fracture in women. Higher doses have been linked to cancer (Dissanayake, 1991; Hussain, 2004; Weinstein and Davison, 2004). Fluorine is present in the lithosphere, atmosphere, hydrosphere and biosphere. A large amount of fluorine can be found in rocks of volcanic origin. It enters the environment through volcanic eruptions, rock dissolution and numerous human activities like coal burning, ore processing, production and use of fertilizers, and industrial plants (Fawell et al., 2015).

Studies have shown that the inhabitants of Langtang North have suffered dental fluorosis, which is an indication of high fluoride concentration in the area. Thus, this study aimed at determining the concentration of fluoride distribution in rocks and water, to ascertain whether or not the fluoride is associated with major rock types; or anthropogenic sources.

\section{MATERIALS AND METHODS \\ Study area}

The study area is located within the north-central part of Nigeria (Figure 1). It has an aerial extent of about $180 \mathrm{Km}^{2}$ defined by latitude $9^{\circ} 04^{\prime} 00 \mathrm{~N}$ and $9^{\circ} 13^{\prime} 49^{\prime \prime} \mathrm{N}$ and longitude $9^{\circ} 44^{\prime} 49^{\prime \prime} \mathrm{E}$ and 9 93'59'"E. This area lies within Wase topographic map, sheet 191SE on scale of 1:50,000. The base map used for the research work was obtained by enlarging this topographic map to a scale of $1: 10,000$.
The geology of the Langtang area and the entire Wase sheet 191SE is not well studied. Literatures of the area are therefore based on the megascopic work done on the Basement of the Jos, Plateau State and Central part of Nigeria. Turner (1971) described the Langtang area as comprising of three major rock types, namely; Alkali-feldspar Syenite, Granite porphyry and Arfvedsonite granite. According to the megascopic studies carried out during the course of this work, about $35 \%$ of the study area is covered by fine-medium grained biotite- granite, $25 \%$ by the alkalifeldspar syenite, $20 \%$ by granite-porphyry, about $8 \%$ by granite-gneiss, and $10 \%$ by quartzites. The remaining $2 \%$ is covered by pegmatite and dolerite dykes. This is in tandem with the findings of Turner (1971).

The hydrogeology of the area is intricately linked to the hydrology and also the climatic conditions prevailing in the study area. The area is well drained by small streams, which are tributaries of river Langtang. Most of these streams are seasonal and retain water only during rainy season.

\section{Methods}

The procedure used for this work was systematic sampling of hand dug wells, boreholes, and streams within the study area. The vicinity of all the sampled wells and borehole were observed to see whether they are clean or located near dumpsites, pit toilets or dirty gutters. This is to ensure that groundwater is free from contamination and pollution.

Two water samples were collected for each well, using a one-liter water bottle. Records of well location, depth to water table, date colour, odour and operating conditions of the well were noted. Before collecting any water sample, the bottles were first rinsed with the water to be sampled. The sample were collected and the index parameters $(\mathrm{pH}$, conductivity and temperature) were measured right there in the field before securely sealing the water bottle. The conductivity of the water samples was measured using the HACH C.O 150 conductivity meter, while $\mathrm{pH}$ was measured using SUNTEX T-S $2 \mathrm{pH}$ meter. The water collected was stored in a cool place 
and was promptly transferred to the laboratory for analysis. Dip meter was used in measuring the depth to water table (static water levels) in all the wells encountered in the study area. Co-ordinates of the location of wells were taken with the aid of the GPS, and were recorded in a field notebook. Water sample was analyzed for fluoride using the IronSelective Electrode (ION 6) METER, while major and minor elements were analyzed using the atomic absorption spectrophotometer (AAS).

Rock and soil samples were also collected in an attempt to relate the distribution of fluoride in groundwater with the geology. During sampling, care was taken to ensure that fresh rocks were sampled and fresh soils sample (dug to the depth of 0.5 to 1 foot). A total of seven samples were collected, (three rocks and four soil samples) and sent to ACT lab Canada for fluoride analysis.

\section{Direct measurement of fluoride using Ion meter}

Twenty (20) mililitre each of water sample (sample 01A) and TISAB1 were poured into a beaker. The solution was placed on a magnetic stirrer and stirred at a constant rate. The ISE equipment was switched on and the MODE key pressed. The electrode probe was then lowered into the solution, while still on the magnetic stirrer and the concentration of fluoride ion in the water sample in millivolt $(\mathrm{mV})$ was read directly from the screen (LCD). The analysis was carried out in triplicate.

\section{Methods of transformation of results}

The Ion Selective Electrode (ISE) equipment used in the analysis measures fluoride concentration in millivolts $(\mathrm{mV})$. This result was converted to milligrams per liter $(\mathrm{mg} / \mathrm{l})$ using a fluoride electrode calibration curve, drawn with the calibration results (Figure 2). The calibration curve was plotted on a semi-logarithm paper. The measured electrode potential in $\mathrm{mV}$ (linear axis) was plotted against the standard concentration (log axis). In the linear region of the curve, only three standards are necessary to determine a calibration curve.

\section{Water classification}

For the classification of water samples of the study area, the Piper trilinear graph was plotted using a computer program 'AquaChem', for ease and accuracy of results.

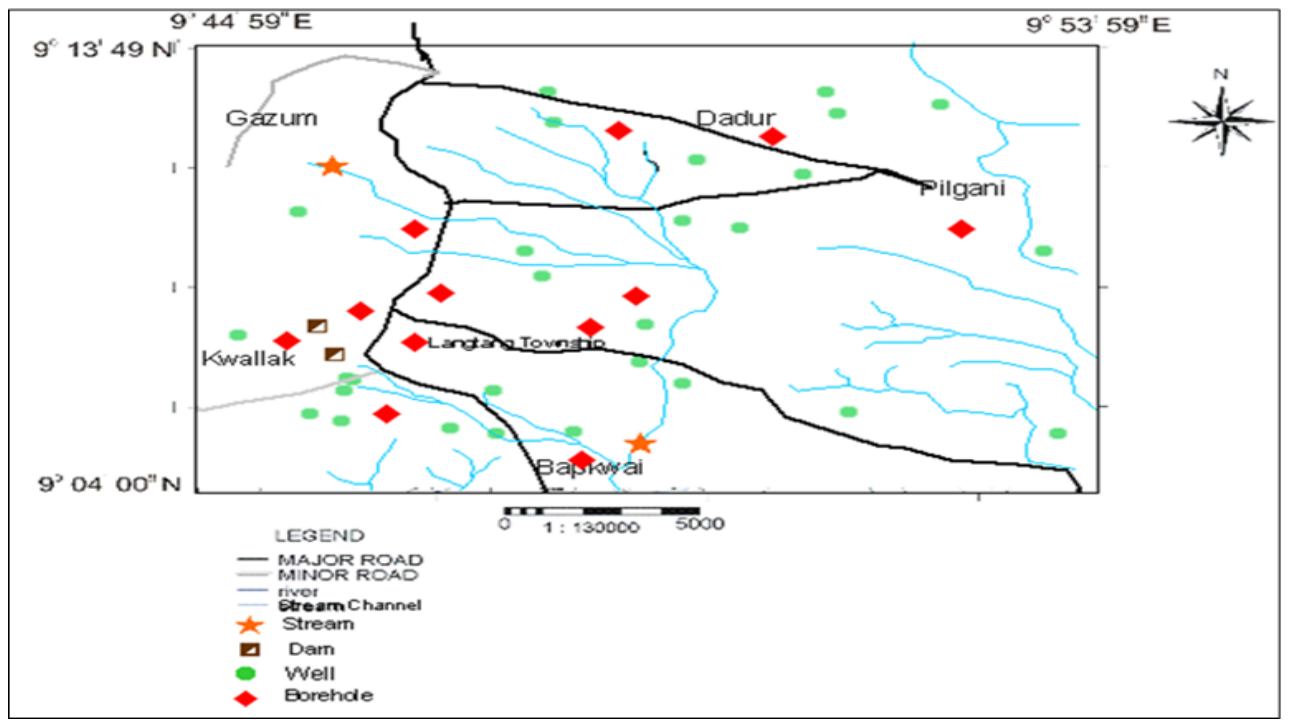

Figure 1: Drainage map of the study area showing the different sampled points. 


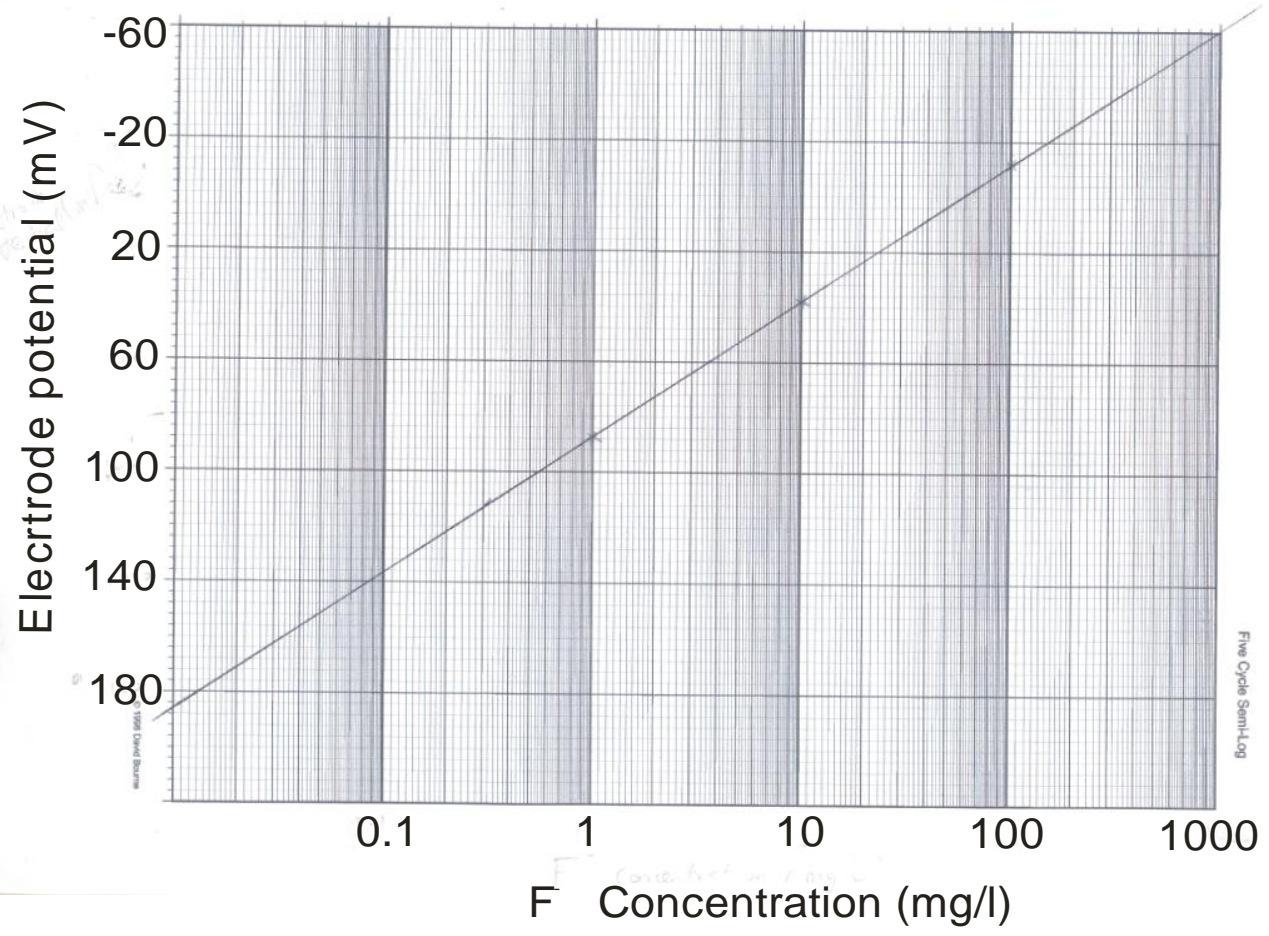

Figure 2: A typical Fluoride calibration curve.

\section{RESULTS}

A total of thirty water samples were collected for the purpose of laboratory analysis. Fourteen from hand dug wells, 12 from boreholes, 2 from streams and 2 from dam. The result of the analysis is presented in the Tables 1 and 2.

The $\mathrm{pH}$ of the water ranges from 7.34 to 8.63 . Conductivity between 750 to 2500 $\mu \mathrm{s} / \mathrm{cm}$, temperature between 27.9 to $33.2{ }^{0} \mathrm{C}$, Hardness between 105.517 to $178.869 \mathrm{mg} / \mathrm{l}$, $\mathrm{Na}^{+}$between 32.21 to $66.05 \mathrm{mg} / \mathrm{l}, \mathrm{Mg}^{2+}$ between 16.24 to $29.99 \mathrm{mg} / \mathrm{l}, \mathrm{Ca}^{2+}$ between 12.49 to $40.24 \mathrm{mg} / 1, \mathrm{HCO}_{3}{ }^{-}$between 109 to $311 \mathrm{mg} / \mathrm{l}, \mathrm{SO}_{4}{ }^{2-}$ between 9.87 to $21.11 \mathrm{mg} / \mathrm{l}$, $\mathrm{Cl}^{-}$between 19.99 to $44.67 \mathrm{mg} / \mathrm{l}$ and $\mathrm{F}^{-}$ between 1.1 to $6.0 \mathrm{mg} / \mathrm{l}$, as shown in Table 1
Table 2 shows the concentration of $\mathrm{Na}^{+}$, $\mathrm{Mg}^{2+}, \mathrm{Ca}^{2+}, \mathrm{Cl}^{-}, \mathrm{HCO}_{3}{ }^{3-}, \mathrm{SO}_{4}{ }^{2-}$, and $\mathrm{F}^{-}$all measured in $\mathrm{mg} / \mathrm{l}$.

Figure 3 shows that the highest fluoride concentration is found around the Northeastern part of the study area, with an average concentration of 3.4 to $3.6 \mathrm{mg} / \mathrm{l}$. While the lowest fluoride concentration of 1.7 to $1.9 \mathrm{mg} / \mathrm{l}$ can be seen around the southern and the Northwestern part of the study area. However, the central portion has shown moderate fluoride concentration. And from the samples analyzed, 83.33 percent contained fluoride concentration above 1.5 $\mathrm{mg} / \mathrm{l}$, while 16.67 percent contained fluoride concentration below $1.5 \mathrm{mg} / \mathrm{l}$. 
M.P. GOYIT et al. / Int. J. Biol. Chem. Sci. 12(2): 1057-1067, 2018

Table 1: Fluoride concentration $(\mathrm{mV})$ and other index parameters.

\begin{tabular}{|c|c|c|c|c|c|c|c|}
\hline Sample No. & Latitude & Longitude & Altitude & pH & Conductivity $(\mu \mathrm{S} / \mathrm{cm})$ & Temperature $\left({ }^{0} \mathrm{C}\right)$ & $\mathrm{F}^{-}$concentration $(\mathrm{mV})$ \\
\hline $1 \mathrm{~A} \mathrm{~W}$ & N09 $04 \div 669^{! !}$ & $\mathrm{E} 009^{0} 48^{!} 920^{! !}$ & 277 & 7.56 & 2500 & 31.4 & 79.8 \\
\hline $2 \mathrm{~A} \mathrm{~W}$ & N09 $04 ! 575^{! !}$ & $\mathrm{E} 009^{0} 49^{!} 051^{! !}$ & 278 & 7.70 & 1500 & 30.3 & 69.1 \\
\hline $3 \mathrm{~A} \mathrm{~B}$ & N09 $04^{\prime} 421^{! !}$ & $\mathrm{E} 009^{0} 49^{!} 040^{! !}$ & 276 & 7.45 & 1000 & 31.6 & 83.7 \\
\hline $4 \mathrm{AS}$ & N09 $05^{\circ} 082^{! !}$ & $\mathrm{E} 009^{0} 49^{!} 201^{! !}$ & 274 & 7.70 & 500 & 31.2 & 79.0 \\
\hline $5 \mathrm{AW}$ & N09 $07 ! 534 ! !$ & $\mathrm{E} 009^{0} 48^{!} 000^{! !}$ & 311 & 7.81 & 2200 & 30.6 & 81.6 \\
\hline $6 \mathrm{AB}$ & N09 $07^{!} 393^{! !}$ & $\mathrm{E} 009^{0} 47^{!} 829^{! !}$ & 313 & 7.34 & 1050 & 33.1 & 72.5 \\
\hline 7AW & N09 $07^{!} 993^{! !}$ & $\mathrm{E} 009^{0} 47^{!} 112^{! !}$ & 336 & 7.91 & 2400 & 30.8 & 52.6 \\
\hline $8 \mathrm{~A} \mathrm{~W}$ & N09 08 ! $022^{! !}$ & E009 $47^{!} 106^{! !}$ & 338 & 7.77 & 1600 & 30.2 & 69.2 \\
\hline 9A D1 & N09 $08^{\circ} 438^{! !}$ & $\mathrm{E} 009^{0} 46 ! 955^{! !}$ & 326 & 8.27 & 2600 & 28.5 & 76.5 \\
\hline 10A D2 & N09 $07^{!} 400^{! !}$ & $\mathrm{E} 009^{0} 47^{!} 053^{! !}$ & 331 & 8.63 & 1800 & 30.1 & 79.1 \\
\hline $11 \mathrm{~A} \mathrm{~W}$ & N09 $07^{!} 917^{! !}$ & E009 $46 ! 816^{! !}$ & 342 & 7.62 & 2040 & 30.2 & 60.7 \\
\hline $12 \mathrm{~A} \mathrm{~B}$ & N09 $07^{\prime} 924^{! !}$ & $\mathrm{E} 009^{0} 4 ! 814^{! !}$ & 342 & 7.34 & 1450 & 30.5 & 53.3 \\
\hline $13 \mathrm{~A} \mathrm{~W}$ & N09 $08^{\prime} \cdot 652^{! !}$ & E009 $47^{!} 188^{! !}$ & 341 & 7.64 & 1900 & 28.9 & 69.9 \\
\hline $14 \mathrm{~A} \mathrm{~W}$ & N09 $08 ! 580^{! !}$ & $\mathrm{E} 009^{0} 47^{!} 246^{! !}$ & 310 & 7.81 & 1050 & 28.8 & 66.7 \\
\hline $15 \mathrm{~A} \mathrm{~B}$ & N09 $07^{\prime} 922^{! !}$ & E $009^{0} 45^{!} 729^{! !}$ & 278 & 7.61 & 1000 & 29.8 & 65.0 \\
\hline $16 \mathrm{~A} \mathrm{~W}$ & N09 $09^{\circ} 005^{! !}$ & E009 $45^{!} 775^{! !}$ & 387 & 8.05 & 2020 & 27.9 & 62.2 \\
\hline $17 \mathrm{~A} \mathrm{~W}$ & N09 $08 \cdot 653^{\prime ! !}$ & E009 $47^{\prime} 629^{! !}$ & 278 & 8.03 & 2000 & 29.4 & 63.3 \\
\hline $18 \mathrm{~A} \mathrm{~B}$ & N09 $08^{0} 600^{! !}$ & E $009^{0} 47^{!} 751^{! !}$ & 311 & 7.97 & 2600 & 29.7 & 70.2 \\
\hline $19 \mathrm{~A} \mathrm{~B}$ & N09 $08^{!} 762^{! !}$ & E009 $47^{!} 955^{! !}$ & 347 & 7.44 & 1480 & 30.5 & 94.3 \\
\hline $20 \mathrm{~A} \mathrm{~B}$ & N09 $09 ! 320^{! !}$ & E009 $48^{\prime} 623^{! !}$ & 313 & 7.82 & 1000 & 29.8 & 49.8 \\
\hline $21 \mathrm{~A} \mathrm{~B}$ & N09 $09 ! 368^{! !}$ & $\mathrm{E} 009^{0} 49^{!} 374^{! !}$ & 320 & 7.91 & 1400 & 32.4 & 48.3 \\
\hline $22 \mathrm{~A} \mathrm{~B}$ & N09 ${ }^{0} 11^{!} 422^{! !}$ & E009 $53 ! 593^{\prime ! !}$ & 274 & 7.69 & 920 & 31.0 & 59.5 \\
\hline $23 \mathrm{~A} \mathrm{~B}$ & $\mathrm{~N}^{0} 9^{0} 11 ! 651^{! !}$ & E009 $53 ! 270 ! !$ & 273 & 7.52 & 2000 & 32.0 & 65.5 \\
\hline $24 \mathrm{~A} \mathrm{~W}$ & N09 $11^{\prime} 497 !$ & E009 $53 ! 434 ! !$ & 277 & 8.02 & 2100 & 31.2 & 61.8 \\
\hline $25 \mathrm{~A} \mathrm{~W}$ & N09 $133^{\prime} 792^{! !}$ & E009 $48 ! 887^{\prime ! !}$ & 379 & 7.90 & 1800 & 30.6 & 85.1 \\
\hline $26 \mathrm{~A} \mathrm{~B}$ & $\mathrm{~N}^{0} 9^{0} 13^{!} 448^{! !}$ & E $009^{0} 49^{!} 489^{! !}$ & 315 & 7.64 & 2010 & 33.2 & 73.6 \\
\hline $27 \mathrm{~A} \mathrm{~B}$ & N09 $13 \cdot 974 !$ & E009 $46^{\prime} 427^{! !}$ & 427 & 7.70 & 2280 & 31.4 & 68.5 \\
\hline $28 \mathrm{~A} \mathrm{~S}$ & N09 ${ }^{0} 13 ! 968^{! !}$ & E009 $466^{\prime} 609^{! !}$ & 419 & 7.64 & 1100 & 30.2 & 88.4 \\
\hline $29 \mathrm{~A} \mathrm{~W}$ & N09 ${ }^{0} 13 ! 990^{! !}$ & $\mathrm{E} 009^{0} 46^{!} 114^{! !}$ & 278 & 7.35 & 1900 & 30.0 & 83.8 \\
\hline $30 \mathrm{~A} \mathrm{~W}$ & N09 ${ }^{0} 12^{!} 147^{!}$ & E009 $47^{\prime} 549^{!}$ & 384 & 7.63 & 750 & 30.2 & 86.2 \\
\hline
\end{tabular}


M.P. GOYIT et al. / Int. J. Biol. Chem. Sci. 12(2): 1057-1067, 2018

Table 2: Transformed fluoride concentration ( $\mathrm{mg} / \mathrm{l})$ and other index parameters.

\begin{tabular}{|c|c|c|c|c|c|c|c|c|c|c|c|}
\hline Sample No. & Latitude & Longitude & Altitude & $\begin{array}{c}\text { Hardness } \\
(\mathrm{mg} / \mathrm{l})\end{array}$ & $\begin{array}{c}\mathrm{Na}^{+} \\
(\mathrm{mg} / \mathrm{l})\end{array}$ & $\begin{array}{l}\mathrm{Mg}^{2+} \\
(\mathrm{mg} / \mathrm{l})\end{array}$ & $\begin{array}{c}\mathrm{Ca}^{2+} \\
(\mathrm{mg} / \mathrm{l})\end{array}$ & $\begin{array}{c}\mathrm{HCO}^{3-} \\
(\mathrm{mg} / \mathrm{l})\end{array}$ & $\begin{array}{l}\mathrm{SO}_{4}{ }^{2-} \\
(\mathrm{mg} / \mathrm{l})\end{array}$ & $\begin{array}{c}\mathrm{Cl}^{-} \\
(\mathrm{mg} / \mathrm{l})\end{array}$ & $\mathrm{F}^{-}(\mathrm{mg} / \mathrm{l})$ \\
\hline $1 \mathrm{~A} \mathrm{~W}$ & N09 $04^{\prime} 669^{! !}$ & E009 $48^{\prime} 920^{! !}$ & 277 & 105.517 & 44.22 & 18.12 & 12.49 & 305 & 16.38 & 20.84 & 1.4 \\
\hline $2 \mathrm{~A} \mathrm{~W}$ & N09 $04 ! 575^{! !}$ & E009 $49^{\prime} 051^{! !}$ & 278 & 155.286 & 48.35 & 26.21 & 19.13 & 183 & 9.87 & 26.80 & 1.8 \\
\hline $3 \mathrm{~A} \mathrm{~B}$ & N09 $04^{\prime} 421^{! !}$ & $\mathrm{E} 009^{0} 49^{!} 040^{! !}$ & 276 & 119.322 & 63.25 & 20.42 & 14.24 & 210 & 19.21 & 44.67 & 1.3 \\
\hline $4 \mathrm{~A} \mathrm{~S}$ & N09 $05^{\prime} 082^{! !}$ & $\mathrm{E} 009^{0} 49^{!} 201^{! !}$ & 274 & 150.862 & 35.44 & 23.82 & 21.28 & 122 & 10.90 & 26.25 & 1.6 \\
\hline $5 \mathrm{AW}$ & N09 $07 ! 534^{! !}$ & $\mathrm{E} 009^{0} 48^{!} 000^{! !}$ & 311 & 117.424 & 47.12 & 28.64 & 15.67 & 244 & 18.18 & 29.28 & 1.7 \\
\hline $6 \mathrm{~A} \mathrm{~B}$ & N09 $07^{\prime} 393^{! !}$ & E009 $47^{\prime} 829^{! !}$ & 313 & 130.584 & 50.64 & 19.24 & 20.68 & 244 & 16.36 & 26.80 & 2.0 \\
\hline $7 \mathrm{AW}$ & N09 $07^{\prime} 993^{! !}$ & $\mathrm{E} 009^{0} 47^{!} 112^{! !}$ & 336 & 167.201 & 45.38 & 17.36 & 38.41 & 183 & 12.73 & 20.84 & 4.0 \\
\hline $8 \mathrm{~A} \mathrm{~W}$ & N09 $08^{0} 022^{! !}$ & $\mathrm{E} 009^{0} 47^{!} 106^{! !}$ & 338 & 126.232 & 66.05 & 20.02 & 17.66 & 200 & 19.12 & 30.33 & 1.8 \\
\hline 9A D1 & N09 $08^{\prime} 438^{! !}$ & $\mathrm{E} 009^{0} 46^{!} 955^{! !}$ & 326 & 114.934 & 35.86 & 16.99 & 18.11 & 198 & 18.33 & 22.98 & 1.7 \\
\hline 10AD2 & N09 $07 ! 400^{! !}$ & $\mathrm{E} 009^{0} 47^{!} 053^{! !}$ & 331 & 119.621 & 32.21 & 19.56 & 15.77 & 212 & 19.12 & 28.22 & 1.6 \\
\hline $11 \mathrm{~A} \mathrm{~W}$ & N09 $07 ! 917^{! !}$ & $\mathrm{E} 009^{0} 46^{!} 816^{! !}$ & 342 & 152.987 & 51.98 & 23.57 & 22.54 & 183 & 10.90 & 19.99 & 3.6 \\
\hline $12 \mathrm{~A} \mathrm{~B}$ & N09 $07^{\prime} 924^{! !}$ & E009 ${ }^{0}{ }^{\prime} 814^{! !}$ & 342 & 147.541 & 42.10 & 25.76 & 16.77 & 300 & 21.11 & 21.21 & 5.4 \\
\hline $13 \mathrm{~A} \mathrm{~W}$ & N09 $08^{0} 652^{! !}$ & $\mathrm{E} 009^{0} 47^{!} 188^{! !}$ & 341 & 129.074 & 36.45 & 19.89 & 19.01 & 123 & 20.09 & 32.09 & 2.3 \\
\hline $14 \mathrm{~A} \mathrm{~W}$ & N09 $08 ! 580^{! !}$ & $\mathrm{E} 009^{0} 47^{\prime} 246^{! !}$ & 310 & 166.974 & 33.02 & 29.89 & 17.77 & 311 & 19.90 & 29.78 & 2.4 \\
\hline $15 \mathrm{~A} \mathrm{~B}$ & N09 $07 ! 922^{! !}$ & $\mathrm{E} 009^{0} 45^{!} 729^{! !}$ & 278 & 159.29 & 44.67 & 26.90 & 19.60 & 198 & 18.18 & 30.03 & 2.8 \\
\hline $16 \mathrm{~A} \mathrm{~W}$ & N09 $08^{0} 005^{! !}$ & $\mathrm{E} 009^{0} 45^{!} 775^{! !}$ & 387 & 163.14 & 48.43 & 29.99 & 16.09 & 244 & 18.39 & 43.44 & 3.02 \\
\hline $17 \mathrm{~A} \mathrm{~W}$ & N09 $08 \div 653^{! !}$ & $\mathrm{E} 009^{0} 47^{!} 629^{! !}$ & 278 & 121.874 & 39.76 & 18.89 & 17.77 & 244 & 17.33 & 44.04 & 3.04 \\
\hline $18 \mathrm{~A} \mathrm{~B}$ & N09 $08^{\prime} 600^{! !}$ & $\mathrm{E} 009^{0} 47^{!} 751^{! !}$ & 311 & 120.99 & 44.53 & 16.90 & 20.68 & 216 & 10.90 & 29.99 & 2.0 \\
\hline $19 \mathrm{~A} \mathrm{~B}$ & N09 $08^{\prime} 762^{! !}$ & E009 $47^{\prime} 955^{! !}$ & 347 & 148.976 & 60.05 & 23.36 & 21.28 & 109 & 19.21 & 22.28 & 2.2 \\
\hline $20 \mathrm{~A} \mathrm{~B}$ & N09 $09 ! 320^{! !}$ & $\mathrm{E} 009^{0} 48^{!} 623^{! !}$ & 313 & 178.869 & 57.90 & 19.09 & 40.24 & 156 & 18.18 & 26.25 & 5.0 \\
\hline $21 \mathrm{~A} \mathrm{~B}$ & N09 $09^{0} 368^{! !}$ & $\mathrm{E} 009^{0} 49^{!} 374^{! !}$ & 320 & 130.728 & 39.87 & 22.33 & 15.67 & 183 & 16.36 & 44.67 & 6.0 \\
\hline $22 \mathrm{~A} \mathrm{~B}$ & N09 $11^{\prime} 422^{! !}$ & E009 $533^{\prime} 593^{! !}$ & 274 & 126.197 & 60.53 & 18.17 & 20.68 & 300 & 16.38 & 29.28 & 2.9 \\
\hline
\end{tabular}


M.P. GOYIT et al. /Int. J. Biol. Chem. Sci. 12(2): 1057-1067, 2018

\begin{tabular}{|c|c|c|c|c|c|c|c|c|c|c|c|}
\hline $23 \mathrm{~A} \mathrm{~B}$ & N09 ${ }^{0} 11^{!} 651^{! !}$ & E009 ${ }^{0} 53^{\prime} 270^{! !}$ & 273 & 143.929 & 66.23 & 23.44 & 19.13 & 289 & 9.87 & 26.80 & 2.7 \\
\hline $24 \mathrm{~A} \mathrm{~W}$ & N09 $111^{!} 497^{! !}$ & E009 ${ }^{0} 53^{!} 434^{! !}$ & 277 & 152.024 & 54.89 & 18.64 & 30.24 & 293 & 10.90 & 22.28 & 3.0 \\
\hline $25 \mathrm{~A} \mathrm{~W}$ & N09 ${ }^{0} 13 ! 792^{! !}$ & E009 ${ }^{0} 48^{\prime} 887^{! !}$ & 379 & 158.834 & 47.08 & 16.24 & 36.90 & 212 & 19.21 & 26.77 & 1.2 \\
\hline $26 \mathrm{~A} \mathrm{~B}$ & N09 $133^{!} 448^{! !}$ & E009 $499^{\prime} 489^{! !}$ & 315 & 123.951 & 61.45 & 17.36 & 21.11 & 183 & 21.10 & 37.07 & 2.1 \\
\hline $27 \mathrm{~A} \mathrm{~B}$ & N09 ${ }^{0} 13 ! 974 ! !$ & $\mathrm{E} 009^{0} 46^{!} 427^{! !}$ & 427 & 131.044 & 66.00 & 19.09 & 25.64 & 244 & 21.00 & 28.31 & 2.6 \\
\hline $28 \mathrm{~A} \mathrm{~S}$ & N09 ${ }^{0} 13 ! 968^{! !}$ & $\mathrm{E} 009^{0} 46 ! 609^{! !}$ & 419 & 115.151 & 34.89 & 17.11 & 18.00 & 234 & 18.89 & 20.84 & 1.1 \\
\hline $29 \mathrm{~A} \mathrm{~W}$ & N09 $139990^{! !}$ & $\mathrm{E} 009^{0} 46^{!} 114^{! !}$ & 278 & 127.839 & 55.53 & 19.54 & 19.09 & 122 & 16.67 & 23.19 & 1.3 \\
\hline $30 \mathrm{~A} \mathrm{~W}$ & N09 $12^{!} 147^{! !}$ & E009 $47^{\prime} 549^{! !}$ & 384 & 138.616 & 43.11 & 20.01 & 22.63 & 183 & 9.99 & 23.90 & 1.2 \\
\hline
\end{tabular}

Table 3: WHO guidance levels for drinking water and the effects of Excess values.

\begin{tabular}{|c|c|c|}
\hline Constituents & Recommended levels (mg/l) & Effects of excess values \\
\hline Sodium & 200 & Taste and can accelerate scale formation and corrosion in boilers. \\
\hline Magnesium & $30-150$ & Hardness of water (scale formation) and has a laxative effect. \\
\hline Calcium & $75-200$ & Hardness of water (scale formation) \\
\hline Chloride & 250 & Salty taste, and $>100 \mathrm{mg} / \mathrm{l}$ may cause physiological damages. \\
\hline Sulphate & 500 & Bitter taste in water containing $>500 \mathrm{mg} / \mathrm{l}$ \\
\hline Bicarbonate & Not mentioned & Hardness of water (scale formation), consumes more soap when washing. \\
\hline Aluminum & $0.05-0.2$ & Aluminum-fluoride interferes with G-proteins in the body. \\
\hline Iron & $0.2-0.3$ & Stains and unpalatable taste \\
\hline $\mathrm{pH}$ & $6.5-8.5$ & Acidity / Alkalinity \\
\hline T.D.S & $500-1000$ & Unpalatable taste \\
\hline Hardness & $75-150$ & Scale formation in boilers and soap consumption \\
\hline Fluoride & $0.7-1.4$ & Between 0.6 and $1.5 \mathrm{mg} / 1$ in drinking water reduces tooth decay, while $>1.5 \mathrm{mg} / 1$ causes dental mottling \\
\hline
\end{tabular}


Table 4: Results showing water analysis of average values of some parameters.

\begin{tabular}{lll}
\hline Parameters & Range & Averages \\
\hline $\mathrm{pH}$ & $7.34-8.63$ & 7.75 \\
Temperature $\left({ }^{\circ} \mathrm{C}\right)$ & $28.8-33.2$ & 30.6 \\
Conductivity $(\mathrm{mS} / \mathrm{cm})$ & $500-2600$ & 1665 \\
T.D.S $(\mathrm{mg} / \mathrm{l})$ & $320-1666$ & 1066.97 \\
$\mathrm{Hardness}(\mathrm{mg} / \mathrm{l})$ & $105.517-178.869$ & 138.17 \\
$\mathrm{Na}^{+}(\mathrm{mg} / \mathrm{l})$ & $32.21-66.23$ & 48.566 \\
$\mathrm{Mg}^{2+}(\mathrm{mg} / \mathrm{l})$ & $16.24-29.89$ & 21.220 \\
$\mathrm{Ca}^{2+}(\mathrm{mg} / \mathrm{l})$ & $12.49-40.24$ & 21.142 \\
$\mathrm{HCO}_{3}^{-}(\mathrm{mg} / \mathrm{l})$ & $122-311$ & 214.27 \\
$\mathrm{SO}_{4}^{2-}(\mathrm{mg} / \mathrm{l})$ & $9.87-21.11$ & 16.492 \\
$\mathrm{Cl}^{-}(\mathrm{mg} / \mathrm{l})$ & $19.99-44.67$ & 28.641 \\
$\mathrm{~F}^{-}(\mathrm{mg} / \mathrm{l})$ & $1.1-6.0$ & 2.492 \\
$\mathrm{Al}^{3+}(\mathrm{mg} / \mathrm{l})$ & $0.01-0.31$ & 0.177 \\
$\mathrm{Fe}^{2+}(\mathrm{mg} / \mathrm{l})$ & $0.04-1.11$ & 0.261 \\
\hline
\end{tabular}
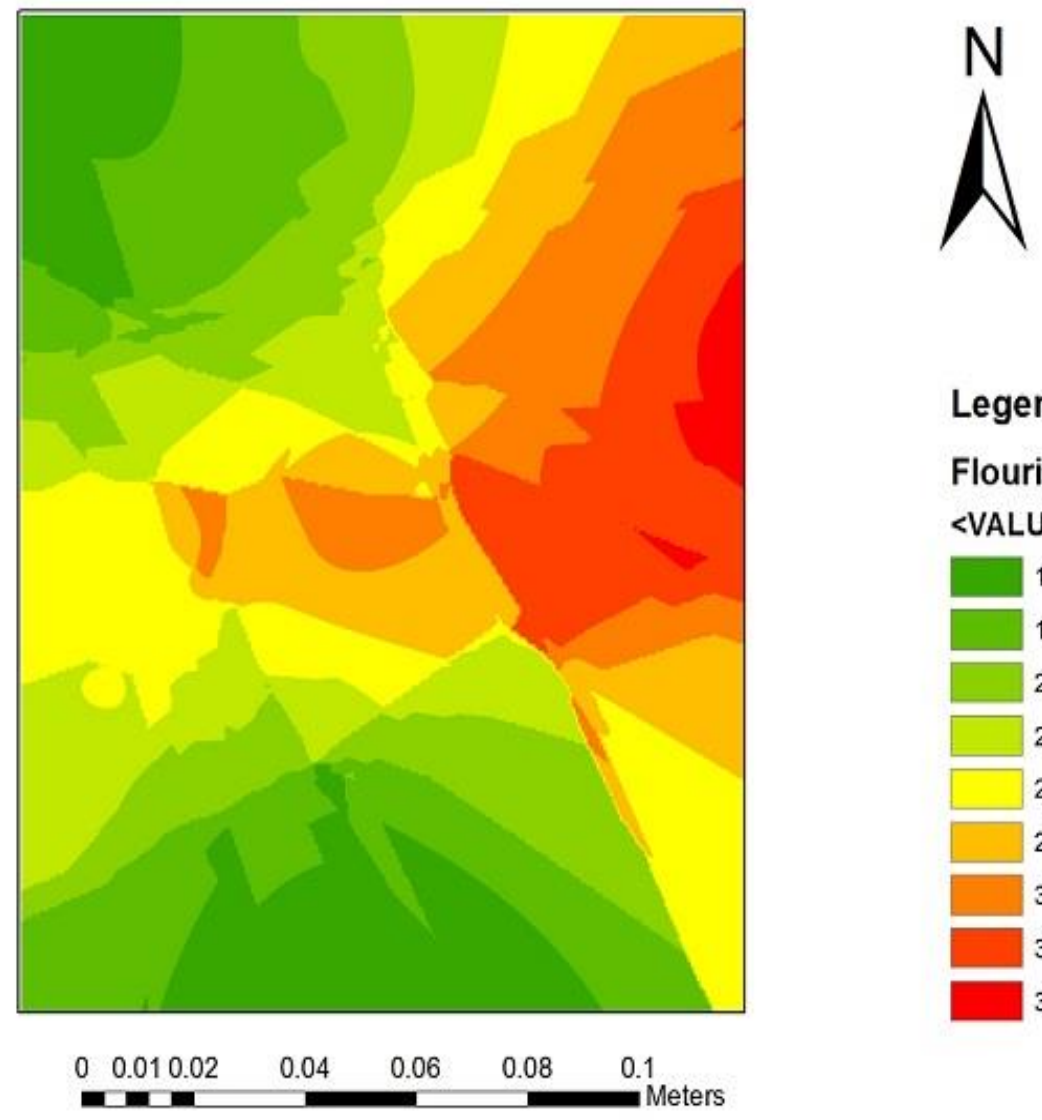

\section{Legend}

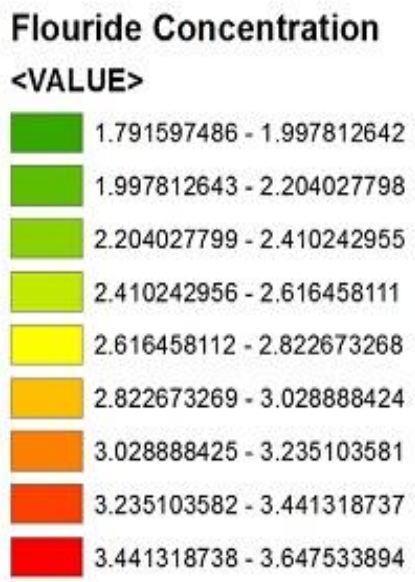

Figure 3: Fluoride concentration distribution map of the study area. 


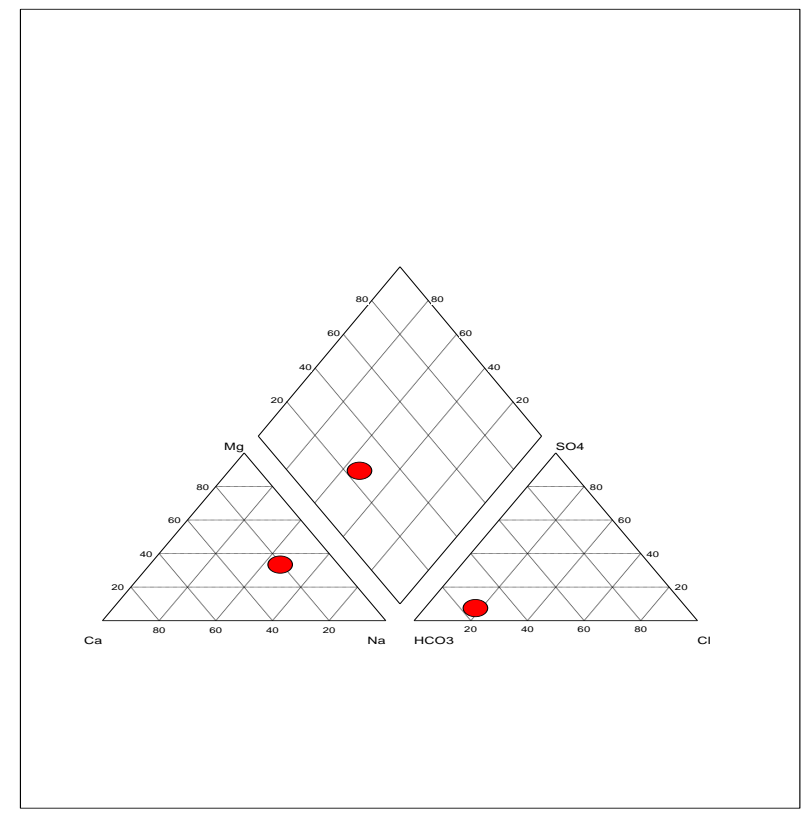

Figure 4: Piper Trilinear graph for well water samples of the study area.

\section{DISCUSSION}

A thorough sampling of different sources of drinking water within LangtangNorth was carried out to understand the relationship between fluoride concentrations in drinking water to the rock type in the environment. Results obtained from fluoride content in soil, which ranges from $100 \mathrm{ppm}$ to $600 \mathrm{ppm}$ is much lower than the fluoride content in rocks of the area ranging from 1600 ppm to $2990 \mathrm{ppm}$. This suggests a slow rate of removal of fluoride ion $\left(\mathrm{F}^{-}\right)$from the rocks, probably due to chemical weathering and leaching of fluoride ion $\left(\mathrm{F}^{-}\right)$rich rocks. If weathering/leaching of fluoride ion $\left(\mathrm{F}^{-}\right)$from rocks were to be normal, the concentration of fluoride ion $\left(\mathrm{F}^{-}\right)$in soils and stream sediments would have been higher (Clark et al., 1990).

The Dolerite dyke shows the highest value of fluorine content of 2,900 ppm, the granite-gneiss and biotite granite show very little variation of $1,700 \mathrm{ppm}$ and $1,600 \mathrm{ppm}$ respectively. This probably could be the result of remobilization of fluoride minerals into the melt at the time of formation. The biotite granite, which has a concentration of 1,600 ppm, appears to be very much higher than the estimated background values of $810 \mathrm{ppm}$ for average low Calcium granites (Clark et al., 1990).

From the samples analysed, $83.33 \%$ has fluoride concentration of above $1.5 \mathrm{mg} / \mathrm{l}$ above the WHO standard of $1.5 \mathrm{mg} / \mathrm{l}$ for drinking water, while $16.67 \%$ were below as shown in Table 2. And these pose a very serious problem of dental and skeletal fluorosis to the inhabitant of the study area. The two dams in the study area have $\mathrm{F}^{-}$ concentration values of 1.7 and $1.6 \mathrm{mg} / \mathrm{l}$, with an average of $1.65 \mathrm{mg} / \mathrm{l}$. This result is higher than that of the streams $(1.35 \mathrm{mg} / \mathrm{l})$, and is probably due to high rate of evaporation. High fluoride concentrations have been reported in natural waters at the rift valley extending to Kenya and Ethiopia, especially in the low land areas with recent volcanic eruptions (Kloos and Haimanot, 1999; Gikunji, et al., 2002).

From results of average concentration of major ions from the different water samples sources, it can be seen that $\mathrm{Ca}^{2+}$ is low, $\mathrm{Mg}^{2+}$ low, $\mathrm{Na}^{+}$high and $\mathrm{HCO}_{3}{ }^{-}$moderate to high in concentrations as shown in Table 2. These 
results are similar to the ones obtained in Njoro division of Nakuru district, Kenya, as defined by Clarke et al. (1990) and other fluoride rich regions, as waters whose chemical composition is derived from normal water-rock interaction at moderate temperatures. The geochemistry of high fluoride groundwater is often associated with neutral to alkaline $\mathrm{pH}$, low calcium concentration and high sodium and bicarbonate concentrations (Chae et al., 2007). Saxena and Ahmed (2001) put forth that alkaline conditions with $\mathrm{pH}$ ranging between 7.6 and 8.6 are favorable for dissolution of fluorite mineral from the host rocks. Sodium bicarbonate type waters are typical of high fluoride waters (Chae et al., 2007).

Calcium ion and $\mathrm{Mg}^{2+}$ are low as they are usually precipitated, largely as carbonates. The concentration of available $\mathrm{Ca}^{2+}$ is important in determining the level of

\section{Conclusion}

The amount of fluoride in rocks as compared with the soils and water sources were significantly different and could be because nature weathering and leaching that takes place. Even with difference in the fluoride concentration the amount of fluoride in the water sources shows high concentration of fluoride above the WHO recommended allowance. Since the waters in the study area are being utilized for drinking and other domestic purposes, then the majority of surface and groundwater sources are in need of defluoridation. However, it would be excessively expensive to provide small defluoridation plants for each such source of water, using presently known methods of partial defluoridation. There is an urgent need for research to be carried out to investigate economic and cost-effective methods of partial defluoridation. In the longer term, only the provision of piped water from centralized water plants where partial defluoridation may be undertaken economically will effectively overcome the problems of excess levels of fluoride. Further works could be carried out to check other effects of high fluoride concentration apart from dental fluorosis. dissolved fluoride in water. Fluorine is incorporated into the calcium carbonate structure and removed from solution when the later precipitates (Hussain, 2004; Weinstein and Davison, 2004). The reaction between Calcium and Fluoride to form Fluorspar $\left(\mathrm{CaF}_{2}\right)$ could also result in low concentration of Calcium ion in the water. Low $\mathrm{Ca}^{2+}$ and $\mathrm{Mg}^{2+}$ are also responsible for the moderate hardness of water within the study area. These findings agree with the hydrogeological investigations carried out in rural parts of Guntur district, Andhra Pradesh, India (Rao, 2009).

The classification water for the various sources of water samples in the study area, as shown in Figure 6, shows that the water is sodium bicarbonate type water $\mathrm{NaHCO}_{3}$. This is true for most areas around the world with high level of fluoride in water (Saxena and Ahmed, 2001).

\section{COMPETING INTERESTS}

We declare that we have no competing interests.

\section{AUTHORS' CONTRIBUTIONS}

The conception and design of the study, interpretation of data, drafting the article and final approval of the version to be submitted was by MPG, OAS and RJK.

\section{REFERENCES}

Brunt R, Vasak L, Griffioen J. 2004. Fluoride in groundwater: Probability of occurrence of excessive concentration on global scale International Groundwater Resources Assessment Centre, Utrecht, Report nr. SP 2004-2.

Chae GT, Yun ST, Mayer B, Kim KH, Kim SY, Kwon JS, Kim K, Koh YK. 2007. Fluorine geochemistry in bedrock groundwater of South Korea. Science of the Total Environment., 385: 1-3: 272283. https//doi.org/10.1016/j.scitotenv. 2007.06.038.

Clarke MG, Woodhall DG, Allen D, Darling G. 1990. Geological, volcanological and hydrogeological controls on the occurrence of geothermal activities in the 
area surrounding Lake Naivasha, Kenya. Ministry of Energy Rep. Nairobi.

Kharb S, Sandhu R, Kundu ZS. 2012. Fluoride levels and osteosarcoma. South Asian J. Cancer, 1(2): 76-77. doi: 10.4103/2278-330X.103717.

Fawell J, Bailey K, Chilton J, Dahi E, Fewtrell L, Magara Y. 2006. Fluoride in Drinking-Water. London: World Health Organization (WHO).

Gikunju JK, Simiyu KW, Gathura PB, Kyule M, Kanja LW. 2002. River Water Fluoride in Kenya, Fluoride, 35(3): 193196.

Hussain J, Sharma KC, Hussain I. 2004. Fluoride in drinking water in Rajasthan and its ill effects on human health. Journal of Tissue Research, 4(2): 263273.

Kloos H, Haimanot RT. 1999. Distribution of fluoride and fluorosis in Ethiopia and prospects for control. Trop Med Int Health, 4: 355-364. DOI: https://doi.org/10.1046/j.13653156.1999.00405.x.

Li L. 2003. The biochemistry and physiology of metallic fluoride: action, mechanism, and implications. Critical Reviews of Oral Biology and Medicine, 14: 100-14. DOI: doi/pdf/10.1177/154411130301400204.

Paul ED, Gimba CE, Kagbu JA, Ndukwe GI, Okibe FG. 2011. Spectrometric Determination of Fluoride in Water, Soil and Vegetables from the Precinct of River Basawa, Zaria, Nigeria. J. Basic. Appl. Chem., 1(6): 33-38.

Rao NS. 2009. Fluoride in groundwater, Varaha River Basin, Visakhapatnam District, Andhra Pradesh, India. Environ Monit. Assess., 152(1-4): 47-60. DOI: doi.1007/s10661-0295-5.
Sadashivamurthy P, Deshmukh S. 2012. Missing links of molar incisor hypomineralization: a review. Journal of International Oral Health, 4: 1-11.

Saxena VK, Ahmed S. 2001. Dissolution of Fluoride in groundwater; a water-rock interaction study. Environmental Geology, 40(9): 1084 - 1087. DOI: https//doi.org/10.1007/s002540100290.

Turner MWN, Buchanan DC, Wright MS, Wright EP. 1971. The Geology of the Jos Plateau. Geological Survey of Nigeria, Bulletin, 32(2): 32-42.

UNICEF, United Nations Children's Education Fund. 1999. A future global agenda for children: The links with sanitation, hygiene, water and environment. A UNICEF Publication on Water, Environment, Sanitation and Hygiene Water, 13: 12-15.

Waszkiel D, Opalko K, Łagocka R, Chlubek D. 2004. Fluoride and Magnesium content in superficial enamel layers of teeth with erosions. Fluoride, 37(4): 271-277.

Waziri M, Musa U, Hati SS. 2012.Assessment of Fluoride Concentrations in Surface Waters and Groundwater Sources in Northeastern Nigeria. Resources and Environment, 2(2): 67 - 72. DOI: 10.5923/j.re.20120202.10.

Weinstein LH, Davison A. 2004. Fluorides in the environment. CABI Publishing, $\mathrm{CAB}$ International, Wallingford Oxon OX10 8DE, UK.

Zoulgami S, Gnazou MDT, Kodom T, Djaneye-boundjou G, Bawa LM. 2015. Physio-chemical study of groundwater in the Northeast of Kara region (Togo). Int. J. Biol. Chem. Sci., 9(3): 1711-1724. DOI: http://dx.doi.org/10.4314/ijbcs. v9i3.49. 